\title{
THE ROLE OF INNOVATIVE ENTREPRENEURSHIP IN ECONOMIC DEVELOPMENT: A CASE OF G2O COUNTRIES
}

\author{
Fayzullokh Sattoriy \\ A Master student of HSE University, Moscow, Russia \\ Behzod Abdupaizov \\ A SAP finance consultant, Tashkent, Uzbekistan
}

Article DOI: https://doi.org/10.36713/epra6108

\begin{abstract}
Innovation and entrepreneurship are considered key factors of growth and survival of modern economies. According to Schumpeter (1934), "carrying out innovations is the only function which is fundamental in history". The review of recent studies reveals that high levels of newly growing up innovative firms are strongly related to economic growth (Stam, 2008).The vinculum of innovation, entrepreneurship and economic development is a matter of great interest at the present time. Given this context, the aim of this study is to explore the relation of Innovative Entrepreneurship and economic growth and its role in economic development of G20 member countries. For this, an overview of literature regarding the impact of innovation and entrepreneurship on economic development is discussed.
\end{abstract}

KEYWORDS: Entrepreneurship, Innovation, Economic Development, SMEs, G20 Countries

\section{INTRODUCTION}

Innovation and entrepreneurship are considered as one of the main drivers of economic growth in the current scenario. Innovation is the implementation of a new or significantly improved product good or service, or process, a new marketing method, or a new organisational method in business practices, workplaces organization or external relations (OECD, 2005). While entrepreneurs "are those business owners who seek to generate value, through the creation or expansion of economic activity, by identifying and exploiting new products, process or markets" (OECD, 2007b). The combination of entrepreneurship and innovation results in innovative entrepreneurship: new firms based on new innovative ideas (Stefan, Comes, Szabo, \& Herman, 2012).

Innovation provides the foundation for new jobs, productivity growth and new businesses due to which competition becomes stiff, and this added competition forces to continue innovating or the businesses may die or their products be commoditized. Innovative economies are more productive, more resilient, more adaptable to change and better able to support higher living standards. Thus it is an important driver of economic growth and development(OECD, 2015). Innovation is the specific tool of entrepreneurs, the means by which they exploit change as an opportunity for a different business or service. It is capable of being presented as a discipline, capable of being learned, capable of being practised (Drucker, P. 2014).

The prior studies have also acknowledged the role of innovation and entrepreneurship in economic development. Schumpeter in his book "The Theory of Economic Development 1911/34" highlighted the relationship between entrepreneurship and innovation and their impact on economic development. He termed "entrepreneur as innovator" and considered innovation as an essential driver of competitiveness and economic dynamics. According to him, innovation is a "process of industrial mutation; that incessantly revolutionises the economic structure from within, incessantly destroying the old one, incessantly creating a new one. (Schumpeter, 1934). "Entrepreneurs are agents of change. Their ability to respond to new opportunities determines how well an economy performs." (UNICE (1999, Fostering Entrepreneurship in Europe; the UNICE Benchmarking Report 1999, Brussels, p.6). Entrepreneurs are critical to the innovation process, and the entrepreneurial capacity is a key element in 
the transfer of knowledge and its commercialization process (Stefan et al., 2012). (Wennekers \& Thurik, 1999; Audretsch \& Thurik, 2001) has identified entrepreneurship as a micro driver of innovation and economic growth. Total entrepreneurial activity is at the core of competitiveness, productivity, innovation and economic growth (Grilo \& Thurik, 2005). Small \&Medium Enterprises and entrepreneurship are key sources of dynamism, innovation and flexibility in developed economies, as well as in emerging and developing economies(Ortega-Argilés, Potters, \& Voigt, 2009).

Waasdorp P. (2002) (Dahlstrand \& Stevenson, 2010) differentiates innovative entrepreneurship from ordinary entrepreneurship. According to them, these two types of entrepreneurship may result in different economic outcomes. Ordinary entrepreneurship mainly contributes to job creation while innovative entrepreneurship leads to higher value-added jobs, wealth creation and firms with higher growth rates which are likely to be more effective, and their founders perhaps more compelled towards growth, by the opportunity of the venture and its innovativeness (Stevenson, L. 2002).

\section{RESEARCH METHOD}

The study is primarily based on secondary data. Pearson's correlation coefficient is used to check the linear relationship between 'national competitiveness' showed by Global Competitiveness Index (GCI), 'innovative performance' showed by Global Innovation Index (GII), 'Necessity and opportunity driven entrepreneurship' as \% of Total Entrepreneurial Activity showed by Global Entrepreneurship Monitor, 'Innovative entrepreneurship' expressed by \% of SMEs (small and medium-sized enterprises) introducing 'product, process, organisational and marketing innovation'; and 'economic growth' expressed in GDP (gross domestic product) per capita of G20 member countries showed by Global Entrepreneurship Monitor. The data is taken for the year 2015, from the annual reports of Global Entrepreneurship Monitor (GEM), Global Innovation Index, Global Competitiveness Report, World Economic Forum (WEF) and UNESCO Institute for Statistics.

\section{Entrepreneurship and Economic \\ Development}

The empirical study highlight that the effect of entrepreneurship and innovation has on economic growth \& development differs according to the development stages of a country. There are three stages of development, namely, the factor-driven stage, the efficiency- driven stage and the innovationdriven stage alike the economic theory of stages of development (Porter et al., 2002).

According to the Global Competitiveness Report 2015-2016 WEF, 2015 out of the 19 economies of the G20member countries representing individually, only one country, India, is at Stage-I being factor-driven, one is in transition from Stage-I to Stage-II Saudi Arabia, three are efficiency-driven economies Indonesia, China and South Africa, five are in transition from Stage-II to Stage-III Russia, Turkey, Argentina, Brazil and Mexico, and the rest are innovation-driven economies.

Increasing competitiveness in less-advanced countries can be achieved by adopting existing technologies or making incremental improvements in other areas, but in the countries that have reached the innovation stage of development, this is no longer sufficient for increasing productivity. "Innovation is particularly important for economies as they approach the frontiers of knowledge, and the possibility of generating more value by merely integrating and adapting exogenous technologies tends to disappear. In these economies, firms must design and develop cutting-edge products and processes to maintain a competitive edge and move toward even higher value-added activities."(WEF, 2015). According to the Global Competitiveness Index, "a comprehensive tool that measures the microeconomic and macroeconomic foundations of national competitiveness" WEF 2012, India ranks $55^{\text {th }}$ out of 140 countries for which the GCI was calculated and it ranks even worse, 120th out of 140 countries, in terms of the "technological readiness", the 9th pillar of GCI. As exhibited in figure (1) there is a positive correlation Pearson's correlation coefficient $=+0.797$ between the level of competitiveness expressed by GCI and economic development GDP/capita in the 19 nations of G20.

The calculations above hence support the hypothesis that the productivity level sets the level of prosperity that can be earned by an economy. It can be noted that factor-driven economies, efficiencydriven economies and those in transition from StageII to Stage-III except Saudi Arabia, have diminished the level of GDP/capita, while only one economy from those in transition from Stage-II to Stage-III, Saudi Arabia, and innovation-driven economies have a higher GDP/capita. The empirical studies also highlight the reason for becoming entrepreneur differs according to the development stage of an economy. The Global Entrepreneurship Monitor Report 2015 outlines that entrepreneurs may choose to enter entrepreneurship for two different reasons, first when they have no other source of income, "necessity-driven", and second when they want to take advantage of a recognised opportunity, "improvement-driven opportunity".

The results of the analysis of the relationship between GDP/capita and Necessity \& Opportunity driven entrepreneurship' as \% of Total Entrepreneurial Activity-TEA which includes those having no other work to do, points out at the existence of a negative correlation at the level of $\mathrm{G}$ 20 countries, for which TEA Pearson's correlation coefficient $=-0.649$, was calculated as shown figure 2(a). 


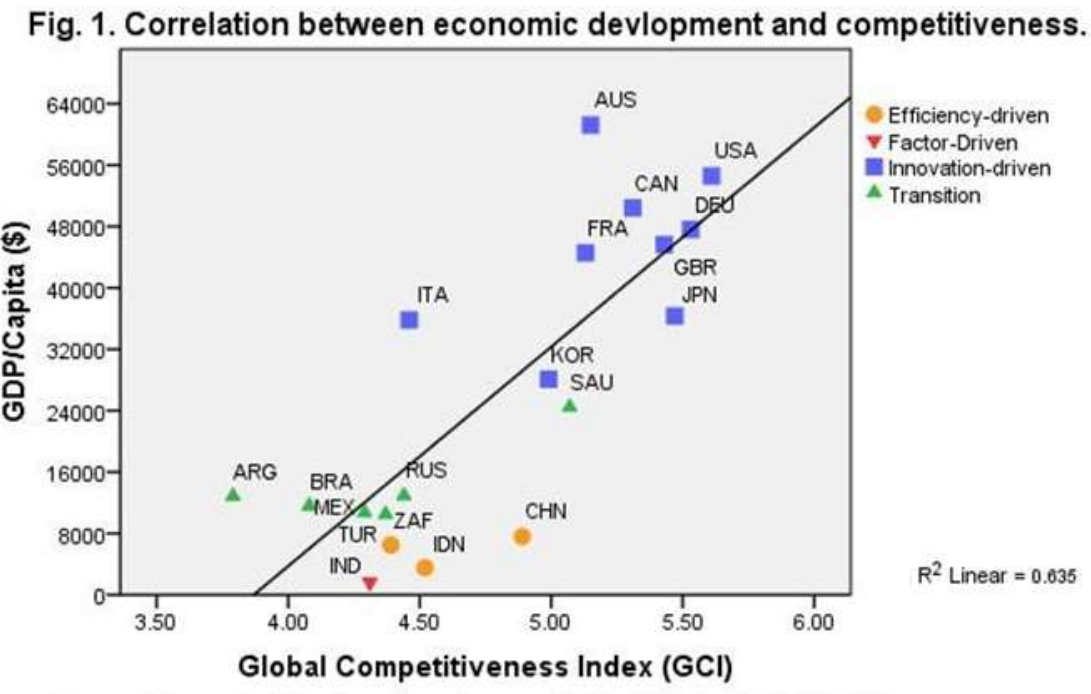

Source: OWn calculation based on data provided by WEF and GEM (2015)

Figure 1: Correlation between economic development and competitiveness

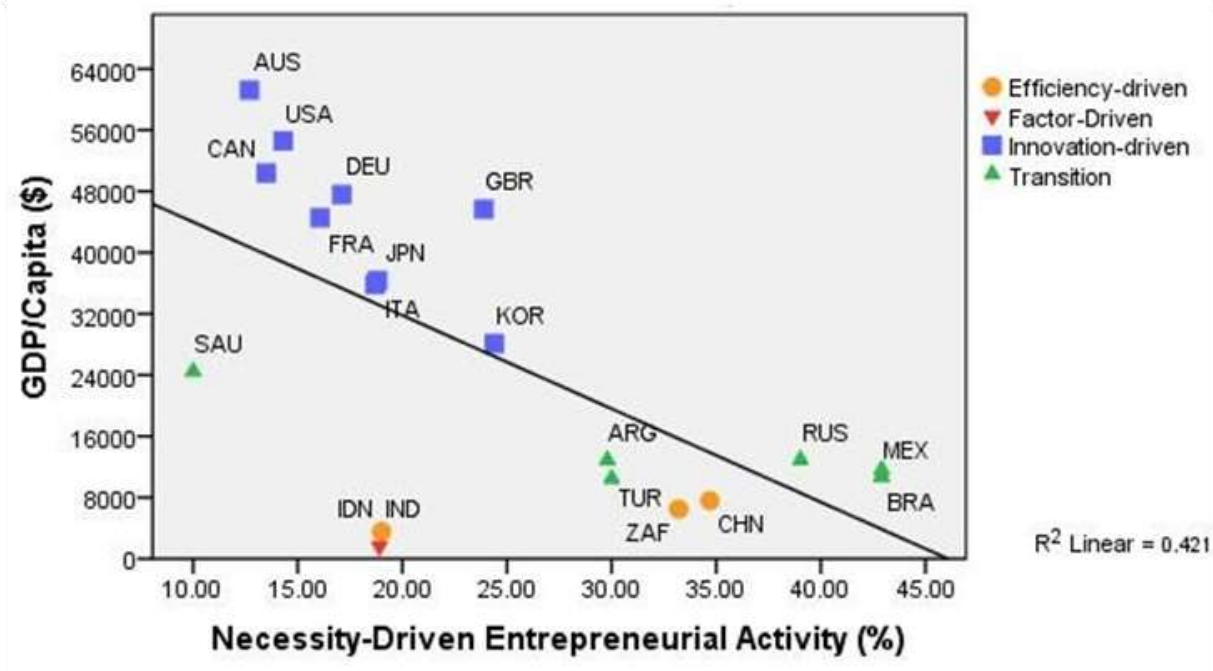

Source: Own calculations based on data provided by global entrepreneuship monitor (2015).

Figure 2 (a): Correlation between necessity-driven enterpreneuship and economic development 
Fig. 2(b). Correlation between improvement-driven entrepreneurship and economic development.

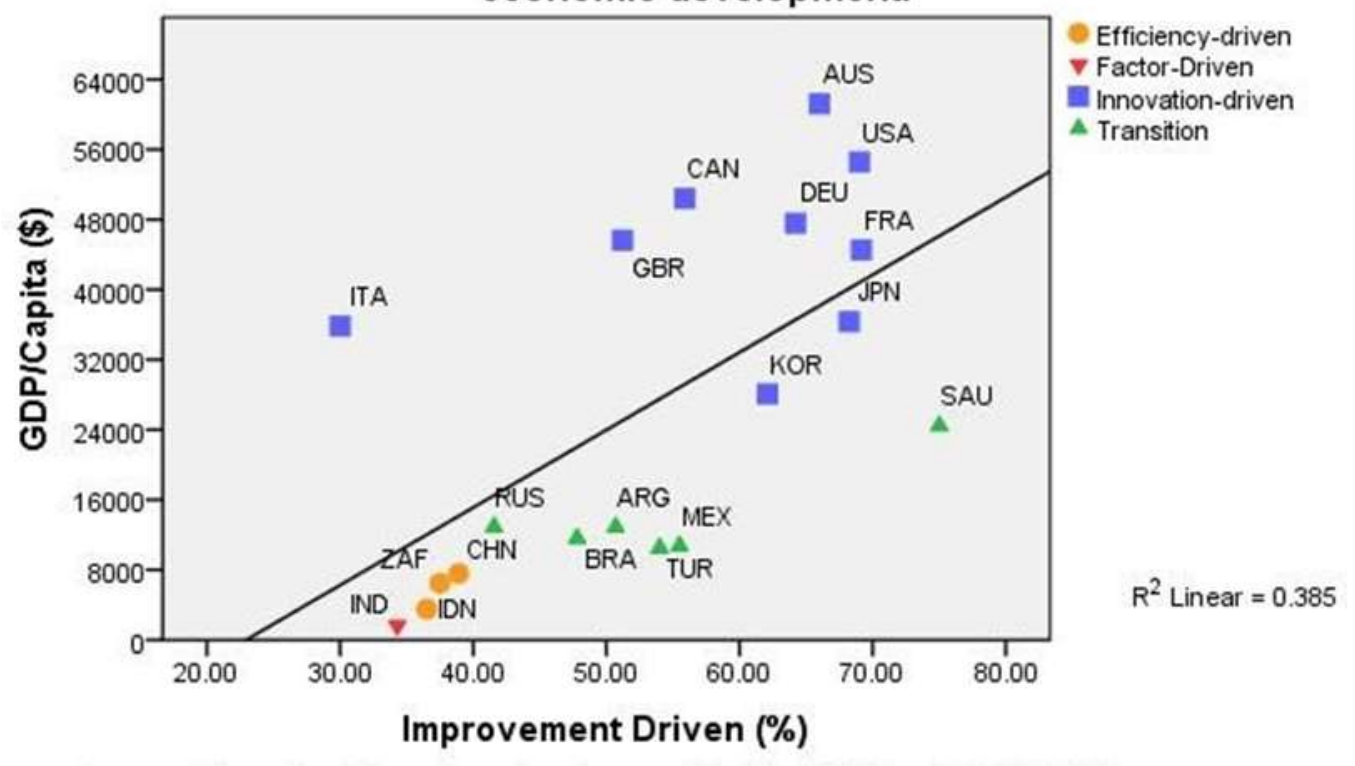

Source: Own calculations based on data provided by WEF and GEM (2015)

\section{Figure 2 (b): Correlation between improvement-driven entrepreneurship and economic development}

Among G 20 countries, those that are in the efficiency-driven stage or in transition to the innovation-drivenstage, "Necessity Entrepreneurship" is higher than those, which are in "innovation-driven" economies. On the contrary, the relationship between GDP/capita and innovation-driven entrepreneurship as \% of Total Entrepreneurial Activity-TEA which claims to be driven by the opportunity rather not finding other work to do, a positive correlation coefficient $=+0.621$, was identified, figure $2(\mathrm{~b})$. Therefore, as the amount economic level increases, that means as it turns from being a factor-driven economy to efficiency-driven economy and then to an innovation-driven economy, necessity as a motivator for entrepreneurship decreases while "improvement- driven opportunity" motives increase. In addition, as the level of economic development increases, innovativeness of entrepreneurs also increases as well (GEM, 2015).

\section{Innovative Entrepreneurship and Economic Development}

According to the "Global Innovation Index, 2015", based on the simple average of input and output sub-index scores, The Innovation Input Index and Innovation Output Index, each build around five and two pillars respectively. Each pillar is then subdivided into three sub-pillars and each of them composed of individual indicators, for a total of 79 indicators. There are three performance groups, these are "Innovation leaders" top 25 countries, all with GII scores above 50 , in which eight G-20 countries were
South Korea/Republic of Korea, Japan, France, United Kingdom, Germany, Canada, United States and Australia, "Innovation achievers" performing $10 \%$ higher than their peers for their level of GDP which include India and China, and "Innovation underperformers" the economies which performed $10 \%$ less than their peers for their level of GDP, Argentina and Indonesia. Some of the countries like Italy, South Africa, Turkey, Mexico, Brazil, Russia and Saudi Arabia are additionally considered as "innovation underperformers" since they underperformed to only that extent where they couldn't fit in any criteria of GII groupings.

Figure 3 shows a direct and strong relationship between Global Innovation Index and GDP/capita. There is a positive correlation with Pearson's correlation coefficient $=+0.782$. Therefore, the gaps between economic developments of the economies can be explained by the variance in the innovative performance. Countries like Argentina, Indonesia, South Africa, Turkey, Mexico, Brazil, Russia and Saudi Arabia where GDP/capita identified to be also reduced have lower innovative performance compared to the G20 average of 45.71 (own calculations). While China and India have sustained a strong innovation performance over the last years and share one commonality of stronger performance in production of knowledge and technologies. Italy has maintained stable ranking since 2014 but couldn't secure a seat among innovative leaders or achievers board due weak performance in some of the innovative performance 
indicators like Growth rate of PPP\$, GDP/worker \%, Intangible assets, ICTs \& business model creation, Gross capital formation, \% GDP, Ease of getting credit, and more.

Recent studies show that the economic development largely depends on innovation, especially on the innovation capacity of enterprises. In order to identify how innovative entrepreneurship influences economic development, we intend to analyze the relationship between SMEs following different innovation indicators incorporated by UNESCO Institute for Statistics (UIS) and GDP/capita. The UIS includes 15 indicators for measuring innovation of which we have included 4 indicators in our study. These indicators are SMEs introducing product \& process innovations (technological innovations) as \% of total SMEs in manufacturing, SMEs introducing marketing \& organizational innovations (non- technological innovations) as \% of total SMEs in manufacturing.

Fig. 3. Correlation between innovation performance and economic development

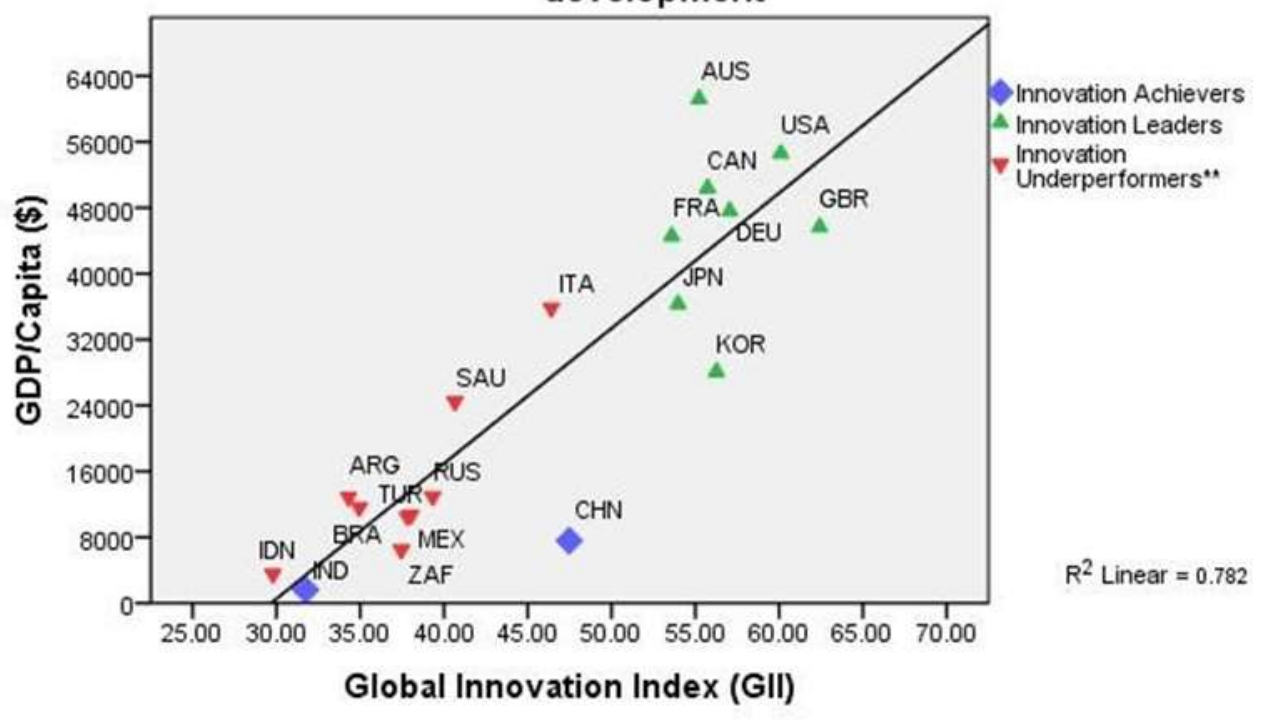

Source: Own calculations based on data provided by GEM and Global innovation index (2015)

Figure 3: Correlation between innovation performance and economic development

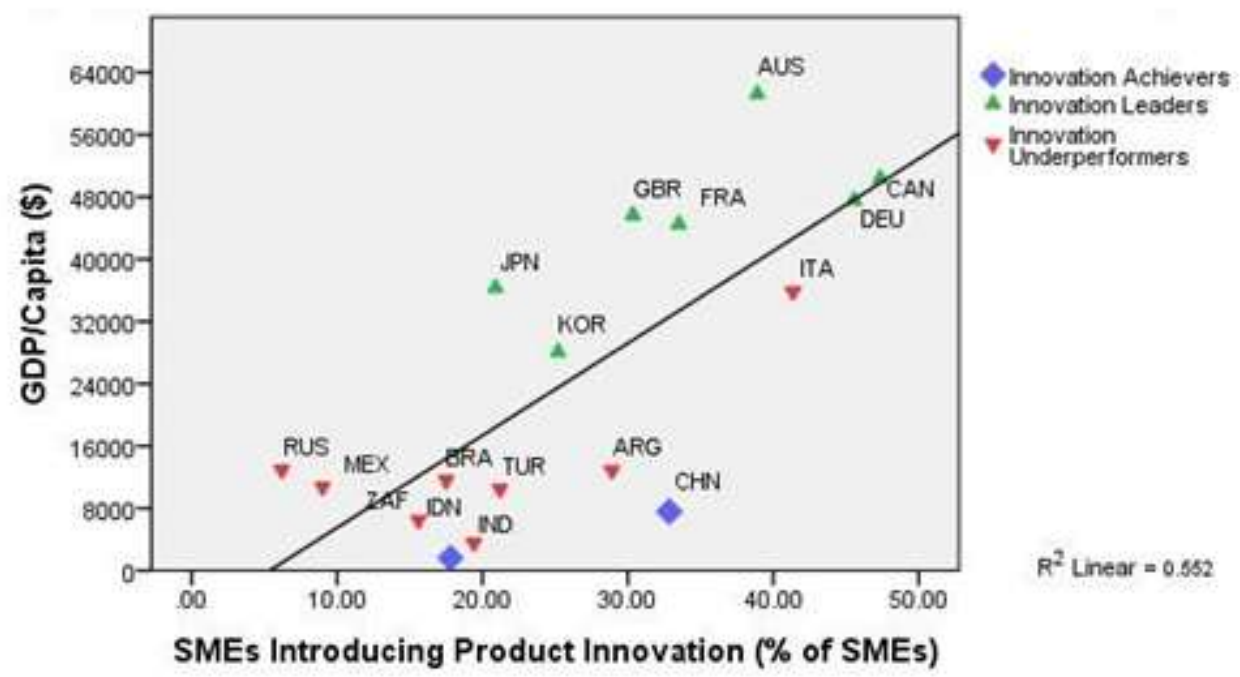

Source: Own caiculations based on data provided by GEM and UNESCO Institute for Statistics (2015)

Figure 4 (a): Correlation between product innovation and economic development 


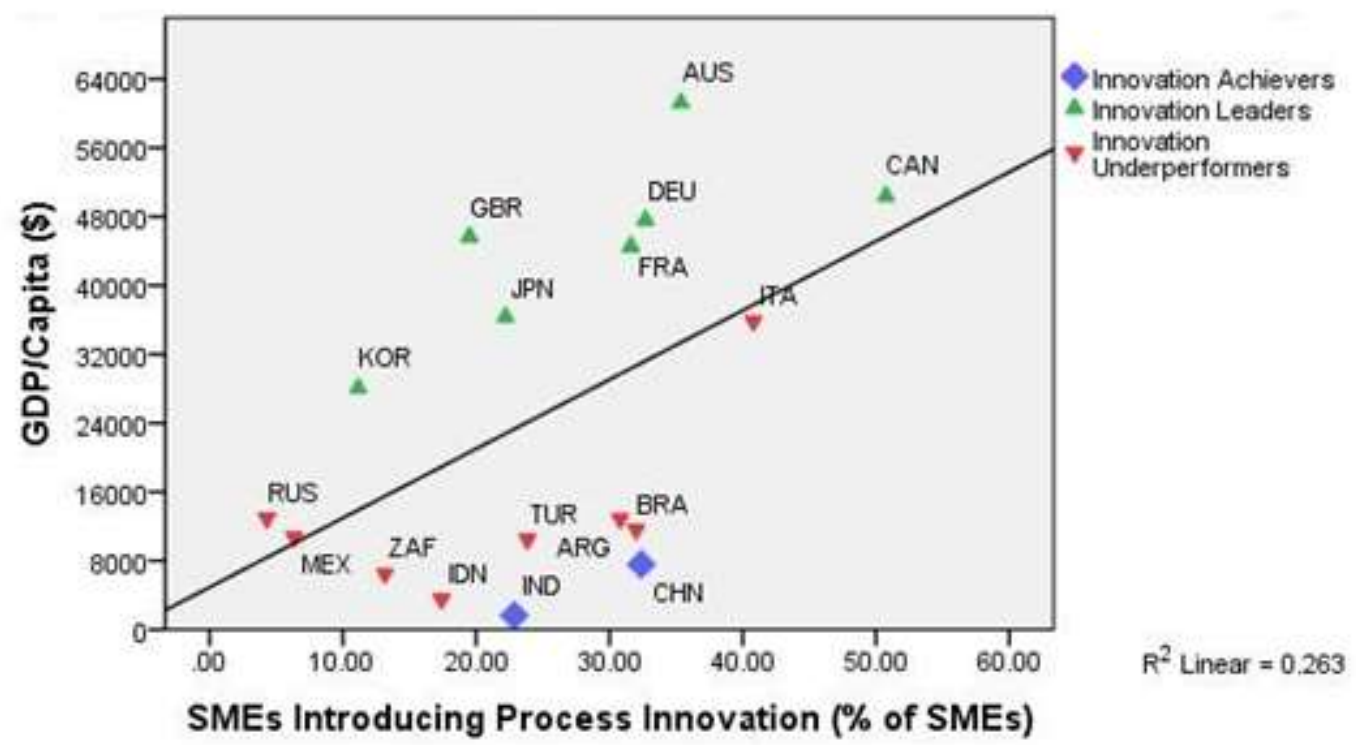

Source: Own calculations based on data provided by GEM and UNESCO Institute for Statistics (2015)

Figure 4 (a) shows a very strong and positive relationship between GDP/capita and SMEs introducing product innovation as \% of SMEs in manufacturing, with Pearson correlation coefficient $=$ +0.743 . The result shows significant differences among the same group of economies in the introduction of new products \& services, though innovation leaders are way ahead of other economies. Figure 4 (b) also shows a positive relationship between GDP/capita and SMEs introducing process innovation as \% of SMEs in manufacturing, with Pearson correlation coefficient $=+0.513$. As for introduction of new processes by SMEs is considered it can be seen that there is a significant difference among the different innovation groups. In comparison with the SMEs introducing product innovation, the countries under innovation leaders tend to be more scattered in SMEs introducing process innovation. While in the countries under innovation achievers and innovation underperformers there is very little difference. The above data shows that the product and process innovations have a positive effect on the economic development in the G-20 countries.
The statistical analysis in figure 5 (a) shows a negative relationship between GDP/capita and SMEs introducing marketing innovation as \% of SMEs in manufacturing, Pearson correlation coefficient $=$ 0.146 which indicates that there is not any significant impact of marketing innovation on economic growth of G-20 member countries. The reason behind the negative relationship is that the countries having higher marketing innovation $\%$ as of SMEs in manufacturing have lower GDP/capita, like Indonesia, India, Brazil \& Turkey.

Figure 5 (b) shows the positive but very weak relationship between GDP/capita and SMEs introducing organizational innovation as \% of SMEs in manufacturing, Pearson correlation coefficient $=+$ 0.093, which reflects that the impact of organisational innovation on the economic development is not of any significance albeit though the analysis shows a positive relationship. The reason being that in the majority of the countries of all three groups, SMEs introducing organizational innovation ( $\%$ of SMEs) falls between $30 \%$ and $50 \%$. 


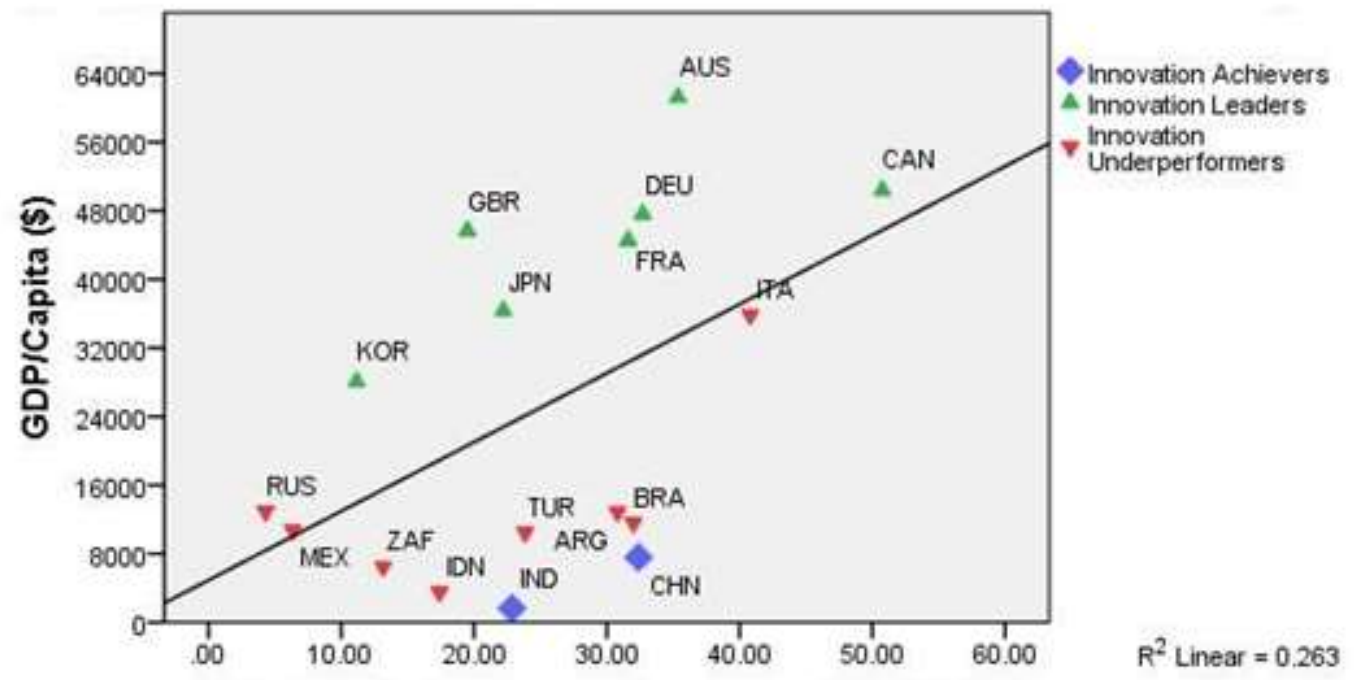

SMEs Introducing Process Innovation (\% of SMEs)

Source: Own calculations based on data provided by GEM and UNESCO Institute for Statistics (2015)

Figure 4 (b): Correlation between process innovation and economic development

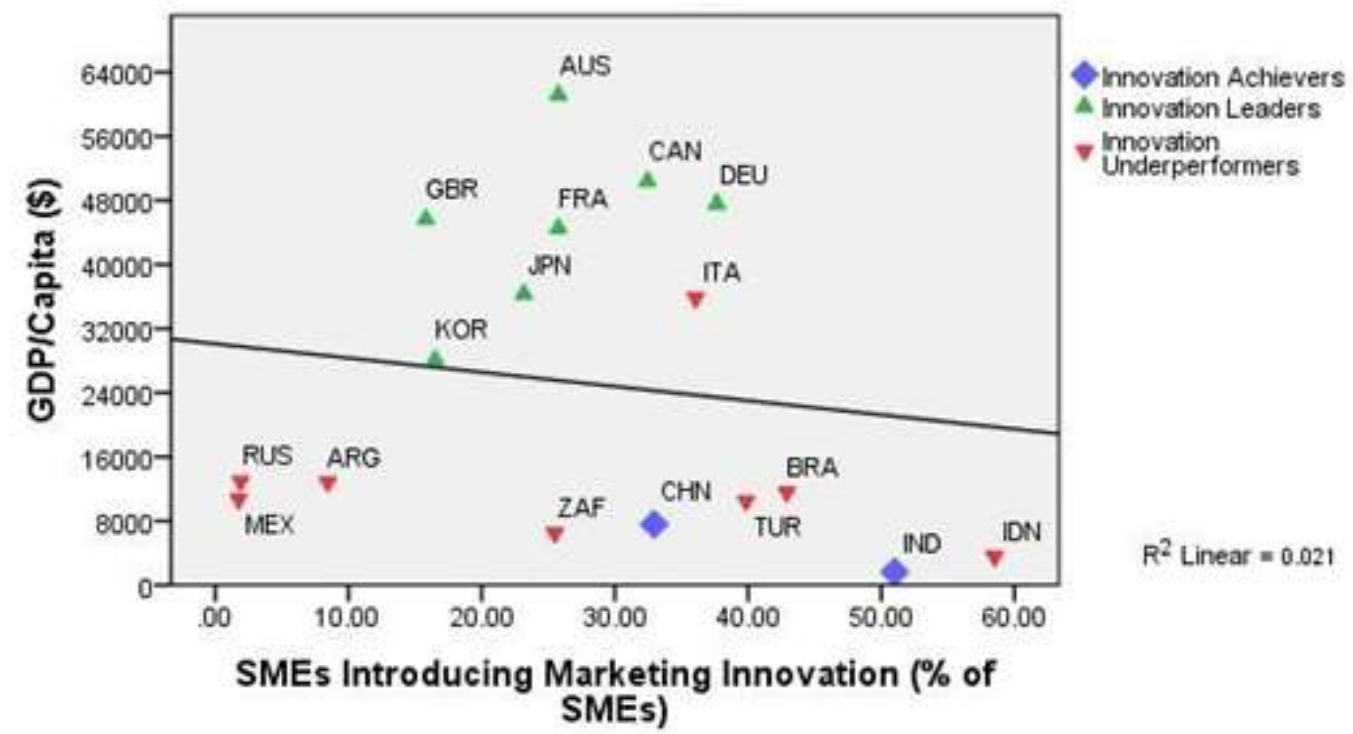

Source: Own calculations based on data provided by GEM and UNESCO Institute for Statistics (2015)

Figure 5 (a): Correlation between marketing innovation and economic development 


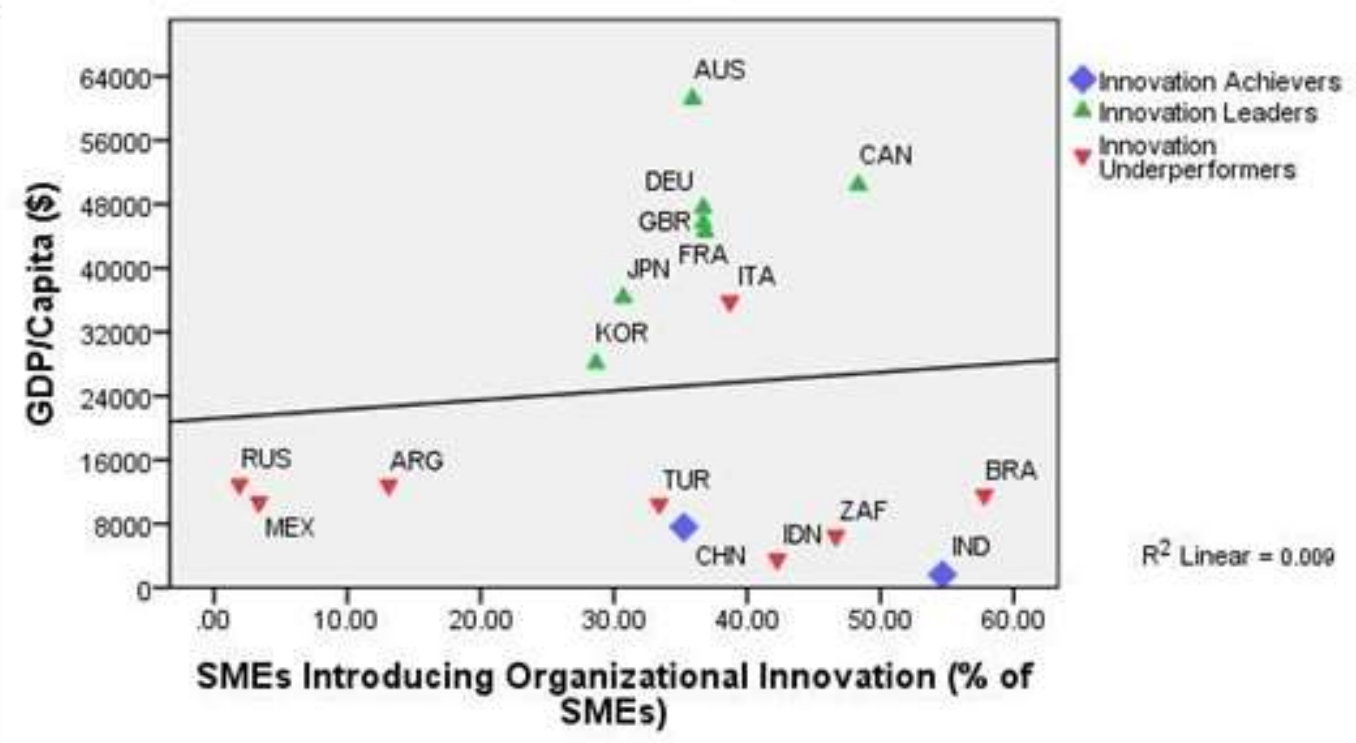

Source: Own calculations based on data provided by GEM and UNESCO Institute for Statistics (2015)

Figure 5 (b): Correlation between organizational innovation and economic development

\section{CONCLUSION}

We have discussed in brief the relationship between the entrepreneurship, innovation and economic growth and various factors that drive these elements, in G20 member countries. The analysis shows that entrepreneurship and innovation, individually and altogether have a positive relationship with the economic growth in general. There is also a negative correlation because of the fact that some of the economies are lagging way behind the average innovative entrepreneurship present in $\mathrm{G} 20$ countries.

The motives of the entrepreneurs in efficiency-driven and those who are in transition from efficiency to innovation-driven economies like Argentina, Turkey, Russia, Mexico and Brazil remains mostly due to "necessity" and all these countries are having reduced GDP/capita while "improvement-driven opportunity" entrepreneurship formed as a concrete motive for the entrepreneurs of innovation-driven economies which are also chart toppers among G20 member nations in economic growth (GDP/Capita). Economies with necessitydriven entrepreneurship, should adopt such policies which educate entrepreneurs about innovative entrepreneurship's powerful economic potential to impact the economic development of their respective nations, help them build organised businesses through expert consultation and also by funding entrepreneurs to run their businesses smoothly and rewarding new idea implementation by them to facilitate a shift from necessity-driven entrepreneurship to improvement- driven opportunity entrepreneurship. SMEs are essential for economic growth. The countries with SMEs adopting innovative entrepreneurship are able to contribute more to economic growth and development. Therefore, the economies like Russia, Mexico, South Africa, Korea and Indonesia need long-term policies that will increase the effectiveness of innovative entrepreneurship of the SMEs. To increase economic growth through innovative entrepreneurship, there should be the promotion of entrepreneurship in general and policies are to be framed focusing on increasing innovative activities among old growing firms.

\section{REFERENCES}

1. Audretsch, D. and Thurik, R. (2001). Linking Entrepreneurship to Growth. OECD Science, Technology and Industry Working Papers, 34. Available: https://doi.org/10.1787/736170038056.

2. Dahlstrand, A. L. and Stevenson, L. (2010). Innovative Entrepreneurship Policy: Linking Innovation and Entrepreneurship in a European Context. Annals of Innovation and Entrepreneurship, 1, pp. 1-15, Available: https://doi.org/10.3402/aie.v1i1.5602

3. Drucker, P. F. (1985). Innovation and Entrepreneurship; Practice and Principles (No. 04; HD2346. U5, D7).

4. Dutta, S., Lanvin, B. and Vincent, S. W. (2015). The Global Innovation Index 2015. Effective Innovation Policies for Development.

5. Grilo, I. and Thurik, R. (2005). Latent and Actual 
Entrepreneurship in Europe and the US: Some Recent Developments. The International Entrepreneurship and Management Journal, 1, pp. 441-459, Available: https://doi.org/10.1007/s11365-005-4772-9

6. OECD (2005). Oslo Manual Guidelines for Collecting and Interpreting Innovation Data. OECD, (3rd ed.), Available: https://doi.org/10.1787/9789264013100-en

7. OECD (2007b). Defining Entrepreneurial Activity: Definitions Supporting Frameworks for Data Collection, Nadim Ahmad and Richard G. Seymour.

8. OECD (2015). OECD Innovation Strategy 2015 An Agenda for Policy Action. OECD Reviews of Innovation Policy, (June), pp. 395-423, Available:

https://doi.org/10.1787/9789264039827-en

9. Ortega-Argilés, R., Potters, L. and Voigt, P. (2009). R\&D-intensive SMEs in Europe: What Do We Know about Them? European Commission-JRC, (15).

10. Porter, M. E., Sachs, J., Cornelius, P. K., McArthur, J. W. and Schwab, K. (2002). The Global Competitiveness Report 2001- 2002 (pp. 16-25). New York, NY: Oxford University Press.

11. Schumpeter, J. A. (1934). The Theory of Economic Development, Harvard University Press.

12. Singer, S., Kelley, D. and Herrington, M. (2015). Global Entrepreneurship Monitor 2015/16 Global Report. Global Entrepreneurship Research Association, pp. 1-78

13. Stam, E. (2008). Linking Innovation and Entrepreneurship Policy. MicroFoundations for Innovation Policy, Available: http://ssrn.com/abstract $=1115262$.

14. Stefan, D., Comes, C.-A., Szabo, Z. K. and Herman, E. (2012). Innovative Entrepreneurship for Economic Development in EU. Procedia Economics and Finance, 3 (12), pp. 268-275, Available:https://doi.org/10.1016/S22125671(12)00151-7

15. Stevenson, L. (2002). Innovation and Entrepreneurship: A Dutch Policy Perspective in an International Context. Entrepreneurship in the Netherlands: Innovative entrepreneurship, New policy Challenges, pp. 43-66

16. The EY G20 Entrepreneurship Barometer (2013). EY-Global. Available: http://www.ey.com/gl/en/services/strategicgrowth-markets/the-ey-g20-entrepreneu.

17. UNESCO Institute for Statistics: UNESCO Institute for Statistics, Available: http://data.uis.unesco.org/\#

18. Waasdorp, P. (2002). Innovative Entrepreneurship: A Dutch Policy

Perspective. Entrepreneurship in the Netherlands: Innovative Entrepreneurship, New policy Challenges, pp. 27-42

19. Wennekers, S. and Thurik, R. (1999). Linking Entrepreneurship and Economic Growth. SMALL BUSINESS ECONOMICS, 13 (1), pp. 2755,Available:
20. https://doi.org/10.1023/A:1008063200484

21. World Economic Forum (WEF), 2015. The Global Competitiveness Report 2015: Full Data Edition 